\title{
Prediction of suicidal ideation in young people from the analysis of texts in social networks written in Mexican spanish: a review of the state of the art
}

\section{Predicción de ideación suicida en jóvenes a partir del análisis de textos en redes sociales escritos en español de México: una revisión del estado del arte}

\author{
AGUILERA-GONZÁLEZ, Gabriel†'*, PADILLA-NAVARRO, Christian', ZARATE-TREJO, Carlos \\ and KHALAF, Georges
}

Universidad Politécnica de Juventino Rosas, México.

"University of Ottawa, Canada.

ID $1^{\text {st }}$ Author: Gabriel, Aguilera-González / ORC ID: 0000-0002-4160-448X

ID $1^{\text {st }}$ Coauthor: Christian, Padilla-Navarro / ORC ID: 0000-0002-8241-3225, CVU CONACYT ID: 427341

ID $2^{\text {nd }}$ Coauthor: Carlos, Zarate-Trejo / ORC ID: 0000-0002-7417-8544

ID $3^{\text {rd }}$ Coauthor: Georges, Khalaf / ORC ID: 0000-0003-2969-6905

DOI: $10.35429 /$ EJS.2020.13.7.29.33

Received July 10, 2020; Accepted December 14, 2020

\section{Abstract}

Suicide prevention is one of the great issues of the current era. Institutions such as the World Health Organization, have continued to search for all possible alternatives for early detection and timely prevention. Suicide rates have grown more and more in the world, and Mexico, although it is not the country with the most suicides, is one of the countries with the highest growth in recent years. At present, the use of social networks has generated great changes in the way we communicate. Expressing yourself through a social network begins to be more common than expressing ourselves to human beings. Several studies, which will be presented later, show that it is possible to determine from the content of social networks: cases of depression, risk of suicide, and other mental problems. The use of technological tools, such as Natural Language Processing, has served as an effective ally for the early detection of risks, such as abuse, bullying or even detecting emotional problems. The present research seeks to carry out an in-depth analysis in the state of the art of the application of Natural Language Processing as an ally for the detection of suicide risk from the analysis of texts for Mexican Spanish in Social Networks.

\section{Resumen}

La prevención del suicidio es uno de los grandes problemas actuales. Instituciones como la Organización Mundial de la Salud, han buscado todas las alternativas para la detección temprana y la prevención oportuna. Las tasas de suicidio siguen creciendo en el mundo, y México, aunque no es el país con más suicidios, es uno de los países con el mayor crecimiento en los últimos años. En la actualidad, el uso de las redes sociales ha generado grandes cambios en la forma en que nos comunicamos. Expresarse a través de una red social comienza a ser más común que expresarse en persona. Varios estudios, que se presentarán más adelante, muestran que es posible determinar a partir del contenido de las redes sociales: casos de depresión, riesgo de suicidio y otros problemas mentales. El uso de herramientas tecnológicas, como el procesamiento del lenguaje natural, ha servido como un aliado efectivo para la detección temprana de riesgos, como el abuso, la intimidación o incluso la detección de problemas emocionales. La presente lleva a cabo un análisis a profundidad en el estado del arte de la aplicación del procesamiento del lenguaje natural como un aliado para la detección del riesgo de suicidio a partir del análisis de textos para el español de México en las redes sociales.

Suicidio, PLN, Español de México

Citation: AGUILERA-GONZÁLEZ, Gabriel, PADILLA-NAVARRO, Christian, ZARATE-TREJO, Carlos and KHALAF, Georges. Prediction of suicidal ideation in young people from the analysis of texts in social networks written in Mexican spanish: a review of the state of the art. ECORFAN Journal-Spain. 2020. 7-13:29-33.

\footnotetext{
* Correspondence to Author (email: sec_acad@upjr.edu.mx)

$\uparrow$ Researcher contributing first author.
} 


\section{Introduction}

The word communication comes from Latin communicatio, and it is the action of transmitting a message through two or more interlocutors (RAE, 2014).

Since the origin of humanity, communication has been fundamental for the growthand development of individuals, as well as an essential process in them.

Specifically talking about human beings, communication has evolved. In the history of humanity, we have found various forms of communication, ranging from the use of cave paintings, the sending of smoke signals, the use of language verbally or in writing, and, more recently, the use of technology.

Psychological projections are a way of communicating, and being more specific, communicating emotions, where word analysis is one of these.

The language can be quite complex, and Spanish is one of the languages with more variants. Being more specific, the Spanish used in Mexico, is different in some cases from the Spanish used in Spain, Colombia, Argentina, and others, adding more complexity to the situation.

For this investigation, due to the specific complexity of the subject of study and the specific use of Mexican Spanish, the investigations specified in the Table 1.

\begin{tabular}{|l|l|}
\hline \multicolumn{2}{|c|}{ Exclusion Criteria } \\
$\begin{array}{l}\text { 1. Articles not written } \\
\text { in Spanish or } \\
\text { English. }\end{array}$ & $\begin{array}{l}\text { 1. Articles published in } \\
\text { Spanish or English. }\end{array}$ \\
\hline $\begin{array}{l}\text { 2. Studies to the full } \\
\text { available. }\end{array}$ & $\begin{array}{l}\text { 2. Articles in which the } \\
\text { objective is the detection } \\
\text { of language and that } \\
\text { includes Mexican Spanish } \\
\text { and articles around the } \\
\text { world in which the } \\
\text { objective is the detection } \\
\text { of suicide risk from the } \\
\text { analysis of the words using } \\
\text { Natural Language } \\
\text { Processing. }\end{array}$ \\
$\begin{array}{l}\text { 3eview, Newspapers, thesis, } \\
\text { toeditor, } \\
\text { letter } \\
\text { posters, thesis, short } \\
\text { reports andbooks. }\end{array}$ & $\begin{array}{l}\text { Articles published during } \\
\text { the last tenyears. }\end{array}$ \\
\hline
\end{tabular}

Table 1 Inclusion and exclusion criteria Source: own work [Word]

\section{Analysis and Classification Problems for Texts Written in Mexican Spanish}

Text analysis in Artificial Intelligence is best known as Natural Language Processing (NLP).

The Natural Language Processing is then a branch of Artificial Intelligence that seeks the analysis, processing and classification of natural language texts such as: English, Spanish, French, Chinese, Portuguese, and even derivations of same, as are Catalan, Galician and Valencian, among others.

\section{The Detection of Language}

When you are working with Natural Language Processing, the first step to take is to correctly detect the language. Some problems that can be located when trying this are:

a) Similar language detection.

b) Detection of multiple languages in the same text.

c) Texts too short to issue a proper classification.

According to (Gimenez, 2016), the Language Identification, (LID), has traditionally been treated as a text classification problem. If we had to formally define the problem, we could say that: "Given a text, of variable length, the task is to decide the language or languages in which it is written from among a set of possible languages."

Although most of the texts we find on social networks are written in English, Spanishspeaking users represent a significant percentage of tweets, posts on Facebook, and in general the activity of other social networks.

In the state of the art, it is also mostly possible to find language detection for English. There is some research for Spanish from Spain, and few for Mexican Spanish.

Similar works are presented in (Maier, 2017) and in (Zampieri, 2013), in which Spanish language detection is carried out for different countries, in which Mexico is present. In the first, they generate their database, while in the second they use a database of the newspaper El Universal. Both use n-grams as a methodology.

In the Table 2 is possible to see a concentrate of the contributions to the state of the art in the appropriate detection of language when applying Natural Language Processing, specifically for Mexican Spanish. 
Maier, Wolfgang. Germany and Spain, 2014

Title: Language variety identification in Spanish tweets.

Purpose(s): Build a balanced collection of tweets sent by Twitter users from five countries, namely Argentina, Chile, Colombia, Mexico, and Spain. Applying different methods, they perform an automatic classification between all countries.

Dataset: They built their own collection of tweets using the Twitter streaming API, 2 requesting all tweets sent within the geographic areas given by the coordinates $-120,-55$ and $-29,30$ (roughly delimiting Latin America), as well as -10, 35 and 3, 46 (roughly delimiting Spain). The download ran from July 2 to July 4, 2014. In a second step, they sorted the tweets according to the respective countries.

Method(s): n-gram.

Best results: $67.7 \%$ correctly classified in some cases. Zamperi, Marcos. Germany and Holland, 2013 Title: N-gram Language Models and POS Distribution for the Identification of Spanish Varieties.

Purpose(s): The paper presents supervised computational methods for the identification of Spanish varieties (Spain, Argentina, Mexico and Peru).

Dataset: For Mexican Spanish, they used the database from El Universal newspaper.

Method(s): n-gram.

Best results: $83.1 \%$ correctly classified for Mexican Spanish.

Table 2 Problems in the Detection of The Language for Mexican Spanish

Source: own work [Word]

\section{Cleaning of the Message}

The second step is the "cleaning of the message", which consists of eliminating those "junk characters" from the text, or trying to make sense of some unlocated words, in order to lose as little as possible of the context of the original message. Specifically, in Mexican Spanish, there are problems that have historically been studied: Sarcasm, irony, drafting errors, modernisms in the language, upper case and lower case, repeated words, hashtags and mentions, spelling mistakes, accents and special characters, anglicisms, among others.

It is essential to mention that, although there are some important contributions fromthe processing of texts on social networks for the English language and a few contributionsfor Spanish from Spain, the specific works for Spanish in Mexico are quite limited, so any contribution is of very important. In (Frenda, 2019) irony detection is performed intweets. This work was the result of a task proposed through the IroSvA competition, which sought to find irony in three types of Spanish: from Spain, from Mexico and from Cuba. In (SalasZárate, 2017), is possible to find a contribution regarding the detection of satire on Twitter for Mexican Spanish.
They generate a database of two types of twitterusers, two formal digital newscasts and two digital newscasts that always use sarcasmin their publications. The pre-processing of the tweets presented in Salas-Zárate is alsointeresting, since they eliminate characters that are used for hashtags and mentions, URLs, among other data that generate an inappropriate classification.

In the Table 3 is possible to review the state of the art of analysis and classificationof problems for texts in social networks written in Mexican Spanish.

\section{Frenda, Simona. Spain, 2019}

Title: Computational Models for Irony Detection in Three Spanish Variants.

Purpose(s): They detect irony in tweets written in Spanish from Spain, Cuba andMexico.

Dataset: The IroSvA shared task is separated on three subtasks: Irony detection in Spanish tweets from Spain, Irony detection in Spanish tweets from Mexico and Irony detection in Spanish news comments from Cuba.

Method(s): They approached irony detection in Spanish short texts trying to exploit the provided topic information. In addition, they investigated the usefulness of stylistic, lexical and affective features during the development of the irony detection models for the three Spanish variants.

Best results: $66.08 \%$ correctly classified for Mexican Spanish.

\section{Salas-Zárate, María del Pilar. Spain, 2017}

Title: Automatic Detection of Satire in Twitter: A psycholinguistic-based approach.

Purpose(s): They evaluated the effectiveness of our method by obtaining a corpus of satirical and nonsatirical news from Mexican and Spanish twitter accounts. The processing of the tweets consisted of: delete mentions and replies to other users tweets, which are represented by means of strings starting with , remove URLs, i.e., strings starting with http://, the "\#" character is removed from all hashtags because often,only the remainder of the string forms a legible word that contributes to a better understanding of the tweet.

Dataset: They used a dataset concerning satirical and non-satirical news from Twitter accounts.

For Mexican Spanish satirical: @eldeforma and @eldizque.

For Mexican Spanishnon-satirical: @ElUniversalMx and Excelsior.

Method(s): LIWC ("Linguistic Inquiry and Word Count").

Best results: $85.5 \%$ correctly classified for Mexican Spanish.

Table 3 Analysis and Classification Problems for Texts in Social Networks Written inMexican Spanish Source: Own work [Word] 


\section{Natural Language Processing for Text Written in Mexican Spanish Applied to Suicide Prediction}

Suicide is one of the great public health problems that humanity seeks to bring down. According to figures from the World Health Organization, 800,000 people commit suicideeach year. Suicide is the second leading cause of death in young people between 15 and 29 years in the world.

Searching in the state-of-the-art natural language processing applications for suicide detection in Spanish, is very limited. In the state of the art, only one Novel techniquehas been located for this case, and it can be seen in the Table 4.

\section{Cook, Benjamín. Spain, 2016}

Title: Novel Use of Natural Language Processing (NLP) to Predict Suicidal Ideation and Psychiatric Symptoms in a Text-Based Mental Health Intervention in Madrid.

Purpose(s): Natural Language Processing (NLP) and machine learning were used to predict suicidal ideation for Spanish from Spain.

Dataset: They work with information from psychiatric inpatient or emergency room settings in Madrid, Spain. Participants responded to structured mental and physical health instruments at multiple follow-up points. Outcome variables of interest were suicidal ideation and psychiatric symptoms (GHQ12).

Method(s): Novel method.

Best results: Between $61 \%$ and $85 \%$ correctly classified for Spanish from Spain.

Table 4 Natural language processing applied to the detection of suicide risk from theanalysis of texts in Spanish

Source: own work [Word]

\section{Analysis of Posthumous Notes Written in Spanish}

As can be seen above, research in the state of the art regarding the search for suicide riskin texts written in Spanish is very poor, while it is void with respect to Mexican Spanish.

One of the principal contributions that can be analyzed, in order to be able to make a suicide risk detection from the texts, is based on the classification of posthumous notes. Although it does not imply the use of computational instruments for its detection, it isimportant to include them given the insufficient information that exists in the state-of-the-art. These investigations can be seen in the Table 5 and in the Table 6 .
Chávez-Hernández, Ana María. Mexico, 2011

Title: Notas suicidas mexicanas. Un análisis cualitativo.

Purpose(s): Natural Language Processing (NLP) and machine learning were used to predict suicidal ideation for Spanish from Spain.

Dataset: They work with information from psychiatric inpatient or emergency room settings in Madrid, Spain. Participants responded to structured mental and physical health instruments at multiple follow-up points. Outcome variables of interest were suicidal ideation and psychiatric symptoms (GHQ12).

Method(s): Ex post facto study, with a sample of 142 suicide notes left by people who committed suicide (2005-2008) in the State of Guanajuato, Mexico.

Best results: 11 categories of suicide risk classification were found from the analysis of texts in Mexican Spanish with statistically significant differences.

Table 5 Detection of suicide risk from the posthumous notes Written in Spanish withoutthe use of computer technique (part 1)

Source: own work [Word]

\section{Ceballos-Espinoza, Francisco. Chile, 2016}

Title: Profiling Chilean Suicide Note-Writers through Content Analysis.

Purpose(s): Natural Language Processing (NLP) and machine learning were used to predict suicidal ideation for Spanish from Spain.

Dataset: All suicide cases recorded from 2010 to 2012 were analyzed by the Chilean Investigative Police, with 203 notes of 96 suicides.

Method(s): Field study, descriptive and ex post facto. Best results: 24 statistically significant differences were found throughout the categories of analysis, according to cohorts of age, marital status and sex of text in Chilean Spanish.

Ceballos-Espinoza, Francisco. Chile, 2019.

Title: Novel Use of Natural Language Processing (NLP) to Predict Suicidal Ideation and Psychiatric Symptoms in a Text-Based Mental Health Intervention in Madrid.

Purpose(s): They explored affective mobilization in the moments prior to the suicidalacts.

Dataset: 203 of suicide notes from completed suicides in Chile (2010 - 2012)

Method(s): Psycological constant comparison and theoretical saturation.

Best results: The findings showed mainly positive affecton, negative affection, depressive affection, and despair. It was concluded that interpersonal problems and emerging afections constituted crucial elements to understand suicidal behavior.

Table 6 Detection of suicide risk from the posthumous notes Written in Spanish withoutthe use of computer technique (part 2)

Source: own work [Word])

\section{Conclusions}

In the present investigation, a search was made of techniques for pre-processing of texts applied to Mexican Spanish, in order to be able to carry out their subsequent classification. 
Also, within the same article, the contributions to the state of the art regardingthe detection of risk of sucidium were analyzed from the analysis of the words using Natural Language Processing, and an additional search of the state of the art regarding a suicide risk detection from the analysis of posthumous notes, not including the use ofcomputational techniques. The state of the art is, in all cases, very poor, so contributions on these issues are essential to strengthen the field of research.

\section{References}

Real Academia Española y Asociación de Academias de la Lengua Española (2014). "comunicación". Diccionario de la lengua española (23va. edición). Madrid: Espasa. ISBN 978-84-670-4189-7

Maier, W. and Gómez-Rodríguez, C. Language variety identification in Spanish tweets. Proceedings of the EMNLP 2014 Workshop on Language Technology for Closely Related Languages and Language Variants. October 2014. Doha, Qatar. Association for Computational Linguistics. doi:10.3115/v1/W14-4204. pp. 25--35.

Zampieri, M., N-gram Language Models and POS Distribution for the

Identification of Spanish Varieties, University of Cologne, Germany., 2013.

Giménez, Maite. Una aproximación basada en aprendizaje automático para diversos problemas de procesamiento de lenguaje natural en redes sociales. Unversidad Politécnica de Valencia. España, 2016.

Frenda, Simona. Computational Models for Irony Detection in Three Spanish Variants. IberLEF@SEPLN; 2019.

Salas-Zárate, María del Pilar, Paredes-Valverde Mario Andrés, Rodríguez-García Miguel Ángel, Valencia-García Rafael, Alor-Hernández Giner, Automatic Detection of Satire in Twitter: A psycholinguistic-based approach, KnowledgeBased Systems (2017), doi: 10.1016/j.knosys.2017.04.009.

Cook, Benjamin L., Ana M. Progovac, Pei Chen, Brian Mullin, Sherry Hou, and Enrique BacaGarcia. 2016. "Novel Use of Natural Language Processing (NLP) to Predict Suicidal Ideation and Psychiatric Symptoms in a Text-Based Mental Health Intervention in Madrid." Computational and Mathematical Methods in $\begin{array}{lll}\text { Medicine } & 2016 \quad(1): & 8708434 .\end{array}$ doi:10.1155/2016/8708434.
Chávez-Hernández, Ana María. Notas suicidas mexicanas. Un análisis cualitativo. Universidad de Guanajuato, Guanajuato (México). Pensamiento Psicológico, Volumen 9, No. 17, 2011, pp. 33-42.

Ceballos-Espinoza, Francisco, ChávezHernández, Ana María. Profiling Chilean Suicide Note-Writers through Content Analysis. Avances en Psicología Latinoamericana / Bogotá (Colombia) / Vol. 34(3) / pp. 517-528 / 2016 / ISSNe2145-4515.

Ceballos-Espinoza, Francisco, San MartínCenteno, Daniel, Chávez-Hernández, Ana María. Movilización afectva eexpeeaada en notae euiciadae chilenae. Análieie adeeade la Teopía Funadamentaada. Revista Argentina de Psicología. Vol XXVIII. N. IV. 2019. doi: 10.24205/03276716.2019.1137.
AGUILERA-GONZÁLEZ, Gabriel, PADILLA-NAVARRO, Christian, ZARATE-TREJO, Carlos and KHALAF, Georges. Prediction of suicidal ideation in young people from the analysis of texts in social networks written in Mexican spanish: a review of the state of the art. ECORFAN Journal-Spain. 2020 